\title{
Irrigation Management for Higher Productivity in Seed Spices-A Review
}

\author{
C.B. Harisha", Honnappa Asangi, Ravindra Singh, N.K. Meena and Gopal Lal \\ ICAR-National Research Centre on Seed Spices, Tabiji, Ajmer, Rajasthan, India \\ *Corresponding author
}

\begin{tabular}{|c|c|}
\hline & A B S T R A C T \\
\hline & \multirow{6}{*}{$\begin{array}{l}\text { Seed spices are important commercial crops of arid and semiarid regions of India and } \\
\text { accounting major contribution for domestic and export market. In these regions water is } \\
\text { one of the main constraint in crop production since the growing areas are deficit in annual } \\
\text { rainfall and these crops are grown during winter season requires assured irrigation for } \\
\text { successful production. Among many irrigation methods including surface irrigation, drip } \\
\text { irrigation and sprinkler irrigation are being followed widely among growing areas depends } \\
\text { on availability of water and micro irrigation facility. But considering the importance of } \\
\text { water for future generation and also present need, it is most necessary to workout optimum } \\
\text { irrigation level, critical stage of water requirement and method of irrigation in seed spices } \\
\text { to save water and to achieve higher productivity. Many research works are carried out on } \\
\text { irrigation scheduling and water requirements of the seed spices on the basis of } \\
\text { meteorological parameters, evapo-transpiration, soil moisture content, soil and leaf water } \\
\text { potential. The review of the literature revealed promising results on irrigation management } \\
\text { in seed spices. Research works on irrigation management in seed spice have been } \\
\text { documented to understand the scope, drawbacks and feasibility to increase the productivity } \\
\text { and to economize the water use. Many of such recommendations and present status of } \\
\text { irrigation techniques and schedules for seed spices are presented in this article. }\end{array}$} \\
\hline & \\
\hline $\begin{array}{l}\text { Irrigation, } \\
\text { Management, } \\
\text { Productivity } \\
\text { and Spices. }\end{array}$ & \\
\hline Article Info & \\
\hline $\begin{array}{l}\text { Accepted: } \\
\text { 26 May } 2017 \\
\text { Available Online: } \\
\text { 10 June } 2017\end{array}$ & \\
\hline & \\
\hline
\end{tabular}

\section{Introduction}

Water is prerequisite for all living beings including crops in agriculture. Water availability for agriculture is under challenge in the world as well as in India. Today, it is more important to use water resources wisely and to irrigate intelligently (Jeelani et al., 2017). Assured irrigation is one of the necessary operations in agriculture particularly arid and semi-arid conditions where rainfall is scanty or limited to shorter period. In high rainfall areas like north east states, Western Ghats, coastal areas where high rainfall and water table makes the crops to survive without assured irrigation. But in areas of arid and semi-arid region where most of the crops are annuals and cultivated by depending on rainfall and irrigation sources like tube wells, canals etc. Among them seed spices are important commercial crops grown in arid and semi-arid regions of India. In these semi-arid areas bringing new irrigation projects and converting most of cultivated area under micro irrigation is very necessary and this can save the water and increase water use efficiency of crops (Singh et al., 2015). In Rajasthan state 75 per cent of the area is under rainfed condition and 35 percent of cropped area is under irrigation facility. Of 
this irrigated area, 70 percent of land is irrigated by tube well and open wells and remaining 30 percent is irrigating by canals. Approximately $1.6 \mathrm{~m}$.ha land is covered under micro irrigation system in Rajasthan state and $0.8 \mathrm{~m}$.ha area in Gujarat as on year 2015. This indicates the potentiality of seed spices to cultivate using this micro irrigation facility and research work carried out in seed spices also implies the scope of micro irrigation in seed spices.

Seed spices are important commercial crops grown for its seed or fruit which is used as spice and condiment in various utilities such as food, bakery, confectionaries, mouth fresheners, pharmaceuticals, etc. Seed spices are collections of a wide variety of volatile and non-volatile staple dietary additives. These spices have been known for ages as effective therapeutic food. The power of seed spices to impart biological activity is now slowly re-emerging as an area of interest for human health (Rathore et al., 2013). The use of spices is increasing worldwide because they are completely natural, rather than artificial additives for seasoning and flavouring foods. Seed spices are consumed as raw spice in food preparation, ground spice, mixed as garam masala, essential oil and oleoresins. But in India use of raw spice is more as compared any other type. Quality in terms of appearance, aroma and flavour components of spices in most important to attract the consumer preference. All the seed spices are belong to Apiaceae except nigella and fenugreek which belongs to Ranunculaceae and Leguminosae, respectively.

\section{Status of seed spices in India}

India being the world leader in seed spice production, consumption and export has to go a long way in the overall development of these crops and their growers. Important seed spices grown in India are cumin, coriander, fennel, fenugreek, nigella, ajwain, dill, anise, celery and caraway. Among these crops cumin, fennel, coriander and fenugreek occupies major area and production. Seed spices are Rabi crops grown in all most all states of the country. Despite of having scattered cultivable area across the country Rajasthan and Gujarat are the dominant seed spices growing states. Total estimated area of seed spices in India is 14.8 lakh hectares with production of 11.6 lakh tonnes during year 2014-15. In coriander area and production Rajasthan is leading state and it is having area of 1.8 lakh hectare and producing 1.1 lakh tonnes per annum. Productivity of seed spices is very less and it is $950 \mathrm{~kg} \mathrm{ha}^{-1}$ in coriander, $530 \mathrm{~kg} \mathrm{ha}^{-1}$ in cumin, $1075 \mathrm{~kg} \mathrm{ha}^{-1}$ in fenugreek and $1680 \mathrm{~kg} \mathrm{ha}^{-1}$ in fennel. There is huge gap to achieve the productivity along with quality spices. We are leader in export of cumin and coriander in the world. During 2014-15 export of cumin and coriander reached 1838.2 and 498 crores respectively.

\section{Irrigation methods and their importance in seed spices}

Major emphasis is being given to improve the irrigation techniques and practices to increase the production and sustainable productivity of crops. Research studies carried out in different countries including India confirmed that irrigation plays a paramount role in increasing the yield and enhancing cropping intensity (Vaidyanathan et al., 1994). In Agriculture various methods are available to estimate the irrigation requirements in crops. One of them is using potential evapotranspiration based on open pan evaporation (Halepyati et al., 1996). Recent trend of scheduling irrigation to crops on the basis of climatological approach has been considered as most effective and scientific, since it consider all the weather parameters in a given climate-plant environment (Parihar et 
al., 1976). Productivity of seed spice crops are less due many factors including good seed, management practices, lack of timely irrigation, pest disease etc. irrigation methods such as surface irrigation methods like flood irrigation, check basin, furrow and ring basin are being followed from long back in which only one half of the water released is utilized for crop production (Lal, et al., 2013). Excessive irrigation along with nutrition leads to vegetative growth and reduces the reproductive phase (Sharma et al., 2016). Increase in the biomass leads to use of more water for biomass production leads reduction in harvest index. Water stress in plants may lead to physiological disorders, such as a reduction in photosynthesis and transpiration. It has been reported that water deficit is a primary factor in increasing oil percentage of medicinal plants and increasing irrigation times significantly decreased the cumin oil percentage. It is reported that water stress affects the crop growth and development, but influence positively on biosynthesis of secondary metabolites and enzyme activities in many medicinal plants (Ahmadian et al., 2011; Laribi et al., 2009; Rebey et al., 2012). Based on this irrigation methods prevailing in seed spices are surface irrigation, sub surface irrigation and micro irrigation. Among these methods surface irrigation by mean of flooding is mostly practiced by farmers.

Surface irrigation methods like flood irrigation, check basin, furrow and ridges, ring basin are being followed from long back in which only half of the water released is utilized for crop production. A significant part of the applied water is lost in application, runoff and evaporation resulting in very low water use efficiency. The conventional systems of irrigation revolving round the concept of replenishing of the moisture level to field capacity after 50 to 60 percent depletion. The system do not permit the restricting of the water to meet the requirement at the root zone, thus leading of the excessive percolation and other losses, which results in problem of water logging, soil salinity and even drought like conditions at tail ends of the system (Lal et al., 2013). Flood method has been used in India for generations without any control what so ever and is called uncontrolled flooding. The water is made to enter the fields either from canals or tube well directly through irrigation channels. In this method water is allowed to flow on the surface of soil to attain the field capacity. Another method of surface irrigation practiced by farmers is check basin method. In this method after sowing of seeds of spices either by broadcasting or seed drill, small and convenient sized plots is being made by tractor drawn bund maker. Water is allowed to each plot through irrigation channels. In check basin method water used is less as compared to flooding in the whole field. Ridges and furrow method of irrigation is practiced very rarely as the seed spices are close spaced crops and lot of area is wasted if rides and furrow method is practiced. Furrow irrigated raised beds wherein irrigation water will reach the root zone by lateral movement and does not allow creating anaerobic condition which may help for better growth and yield of cumin (Singh et al., 2015).

Sub-surface irrigation, as name suggested the application of irrigation water to fields directly to the root zone of the plants. The main advantages of these type of irrigation is reduction of evaporation losses and less hindrance to cultivation works which takes place on the soil surface. Among sub surface irrigation drip and sprinkler irrigation plays significant role and occupies major areas of micro irrigation.

In drip method of irrigation water is applied to root zone of soil drop by drop so that only required amount of water is applied to the crop based on evapo-transpiration or soil 
moisture status. Drip fertigation method offers nutrients application directly into the zone of crop and consequently fertilizer-use efficiency can be improved over conventional method of fertilizer application (Hebbar et al., 2004). Reduction in water consumption due to drip method of irrigation over the surface method of irrigation varies from 30 to 70 percent for different crops (Lal et al., 2013). In arid western Rajasthan, drip irrigation on the basis of climatologically approach hold great promise for minimizing water loss and improving its efficiency and ultimately productivity (Bhunia et al., 2015). It is also suitable for wider spaced crops like fennel, ajwain, dill, celery and even narrow spaced crops such as coriander, fenugreek. Only thing is lateral spacing and spacing of drippers is to be considered while laying out the drip system in seed spices.

In case of sprinkler irrigation system either micro sprinklers or macro sprinklers water is applied in the form of rain. Even though evaporation and drifting loss of water is more in this method required volume of water may be applied (Hassan and Ali, 2016).

Sprinkler system provides the imitation of raining so that crops perform better with improved micro climate. But possibilities of disease incidence are more due increased relative humidity in the crop zone. In many crops like cumin, coriander, fenugreek, nigella where crop height is less can be equipped with sprinkler irrigation system and in long statured crops like fennel, dill and celery height of raiser is to be increased.

\section{Problems with existing irrigation systems in seed spices}

Presently surface irrigation system is widely following in seed spices cultivation. In this method farmers follow flood irrigation by allowing the irrigation water to flow in the field as it required. This leads to loss of huge water by percolation and runoff.

Soil salinity due to excessive and unnecessary irrigation by flood irrigation in clay soils has become major problem (Godara et al., 2013).

In small statured and closely spaced crops such as nigella, anise and cumin adopting drip irrigation method is difficult and needs special attention in installation of drip irrigation facility.

Cumin is highly sensitive to water stagnation. But sprinkler irrigation system will creates the humid condition the field which is favourable for incidence of Alternaria blight disease (Arvind et al., 2016).

In the same way light irrigation under surface irrigation method (check basin method) create anaerobic conditions for few hours after irrigation may severely affect the fully developed plants by blight incidence (Singh et al., 2015).

Since many of the seed spices are sown by broadcasting or by seed drills lead improper spacing for laying out drip irrigation system.

Lack of awareness among the farmers regarding technique to use drip irrigation system in seed spices, volume of water to be applied, stage of irrigation, frequency of irrigation and ideal fertigation technique.

\section{Effect of irrigation on seed spices}

Many researchers worked on irrigation management in seed spices and it has found many useful results to improve growth, biological yield, seed yield, water use efficiency and quality of produce.

In seed spices optimum irrigation is necessary to obtain high yield and good quality produce. 
The review of all the work carried out in seed spices are summarized here under.

\section{Cumin (Cuminum cyminum)}

Cumin is a major seed spice crop with a short growing cycle, which demands little moisture and nutrient inputs. Generally cumin crop matures in about $110-120$ days. It is being cultivated in arid regions of Gujarat and Rajasthan where soils are sandy in nature and remarked with very less rainfall. As a rabi crop cumin needs assured irrigation to germinate and maturity of crop. It is a less biomass yielding crop of arid regions. It is known that cumin is one of the drought tolerant crop in low rainfall areas, which has high water use efficiency and produces satisfactory yields with low amount of water consumption (Samadzadeh et al., 2016). Cumin is highly sensitive to water stagnation. Light irrigation under surface irrigation method creates anaerobic conditions for few hours may severely affect the fully developed plants (Singh et al., 2015).

Irrigating cumin crop either with drip irrigation or micro sprinkler irrigation gave better seed yield as compared to surface irrigation (Singh et al., 2015). They found that water productivity was improved by drip irrigation method $(41.28 \mathrm{~kg} / \mathrm{ha} \mathrm{cm})$ followed by micro sprinkler $(21.73 \mathrm{~kg}$ seed/ha $\mathrm{cm})$ against surface irrigation method $(8.43 \mathrm{~kg}$ seed /ha cm). Bondok and Amal, (2014) reported that saving in irrigation water by using sprinkler irrigation system was $46 \%$ in comparing with surface irrigation in cumin crop. Seed yield of cumin increased by $10-12$ percent under sprinkler system irrigation comparing with surface irrigation. Water use efficiency of cumin crop under surface irrigation decreased by 52 percent comparing with sprinkler irrigation. Use of micro sprinklers is not advocated in cumin due to requirement of more energy than drip system, incidence of pest and disease in sprinkler (Arvind et al., 2016). It also reported that drip irrigation with $0.8 \mathrm{IW} / \mathrm{ETc}$ resulted higher seed yield, plant height and dry matter of $1344.17 \mathrm{~kg} \mathrm{ha}^{-1}, 36.42 \mathrm{~cm}$ and $2365 \mathrm{~kg} / \mathrm{ha}$ respectively at $0.8 \mathrm{IW} /$ Etc and also highest water use efficiency $(5.58 \mathrm{~kg} / \mathrm{ha} . \mathrm{mm})$ was observed at $0.6 \mathrm{IW} / \mathrm{Etc} .53 .3$ percent of water can be saved if cumin crop is irrigated at 0.8 IW/ETc as compared to surface irrigation method. Mehta et al., (2014) reported that the optimum moisture status in the root zone of the cumin crop through irrigation at 18 days interval favoured higher yield attributes which increased seed, straw and biological yield of cumin over 12 and 15 days intervals. The cumin seed yield decreased significantly with decreasing irrigation from $0.8 \mathrm{IW} / \mathrm{CPE}$ to 0.4 IW/CPE by micro sprinkler method. The highest cumin seed yield of 609 and 746 $\mathrm{kg} / \mathrm{ha}$ was obtained at $0.8 \mathrm{IW} / \mathrm{CPE}$ which is significantly higher over 0.4 IW/CPE treatments that recorded only 330 and 514 $\mathrm{kg} / \mathrm{ha}$ seed yield during two consecutive years, respectively. However, further increase in irrigation level to $1.0 \mathrm{IW} / \mathrm{CPE}$ was not proved beneficial for cumin.

It is also proved that highest irrigation water productivity was recorded at $0.8 \mathrm{IW} / \mathrm{CPE}$ treatments, i.e., 0.281 and $0.340 \mathrm{~kg} \mathrm{~m}^{-3}$ of water during two years and it reduced with increase in irrigation level (Rao et al., 2010). Cumin is tolerant to saline water irrigation and it is reported that maximum salinity tolerance for economical cumin yield is 5.0 $\mathrm{dS} . \mathrm{m}^{-1}$ and the most sensitive stage of growth to salt water stress in the vegetative and reproductive stages are establishment and the flowering stage (Hassanzadehdelouei et al., 2013).

Essential oil content of cumin seed was observed decreasing trend with increasing irrigation levels. Increased irrigation frequencies in cumin at three times from 
sowing, flowering and seed-filling stages enhanced the plant growth, seed and essential oil yields (Samadzadeh et al., 2016).

\section{Coriander (Coriandrum sativum L.)}

Coriander is second most important seed spice crop grown for its seed as well as herb. It needs adequate moisture for its growth and development. It is possible to limit the number of irrigation up to pre-flowering stage but it is necessary to provide optimum irrigation to coriander crop at the time of flowering and seed setting stage (Verma et al., 2015) and it is reported that drip irrigation at 80 percent and along with foliar spray of 25 percent nitrogen is beneficial for coriander to achieve higher seed yield. Irrigation at higher levels resulted in the highest vegetative growth and yield components in coriander compared to the lower levels (Osman and ElFeky, 2005). Flower initiation and seed development are the two critical stages of coriander for water requirement (Singh et al., 2002) and Moniruzzaman et al., (2013) reported that three irrigations at branching (30 DAS), flowering (60 DAS) and seed-filling stage (90 DAS) was ideal for higher coriander productivity and water use efficiency in coriander. Verma et al., (2015) and Lakpale et al., (2007) also reported that deficit drip irrigation at vegetative stage $(60 \%$ ETc) followed by optimum irrigation in reproductive and seed development stages (80\% ETc) improved the yield attributes and seed yield in coriander. This helped in increase in root growth during initial stages and later it utilizes water effectively. Tripathi et al., (2009) reported that, the seed yield of coriander was significantly improved by three irrigations at 20, 40 and 60 DAS by increasing the seed yield (1.96 tonne/ha) and resulted 38.31 percent and 3.93 percent in seed yield at two irrigations (at 20 and 40 DAS) and four irrigations (20, 40, 60 and 80 DAS) respectively. Eight irrigations at 15 days interval recorded higher seed yield in coriander (Sharangi and Roychowdhury, 2014; Hassan, et al., 2012). Increasing irrigation level upto 120 percent of ET will increases the seed yield and oil percentage in coriander seeds but water use efficiency decreases as increase in irrigation levels (Hassan and Ali, 2014).

It is reported that essential oil yields per plant increased significantly with increasing water regimes from 50 percent to 100 percent of the crop water need but linalool content of oil was reduced when increasing irrigation level

\section{Fennel (Foeniculum vulgare Mill.)}

Fennel is one of the highest biomass yielding crop among seed spices (Sonu et al., 2016). It is sown as direct seeded as well as transplanted (Mehta et al., 1990). Transplanted fennel can reduce the water use for initial 45 days of nursery period as compared to direct seed sown crop in the field. Productivity of fennel is low because of improper irrigation and nutrient supply. Bhunia et al., (2005) reported that irrigation and fertigation improved the productivity of fennel and they found that irrigation treatment of IW: CPE ratio of 0.8 significantly out yielded the IW: CPE ratio of 0.4 and 0.6 irrigation levels. Higher irrigation frequency increased the availability of nutrients and thus enhanced the uptake of nutrients fennel. In another study Meena et al., (2014) reported that fennel crop needs six surface irrigations at 20 days interval for higher productivity with use of straw as mulch. This will increase the seed yield of fennel by 37 percent as compared to four surface irrigations. Use of modern irrigation techniques to increase the efficiency of water use is important. In this regard irrigating fennel crop at $0.55 \mathrm{CPE}$ volume by drip irrigation gave fennel seed yield of $14.72 \mathrm{qt} \mathrm{ha}^{-1}$ as compared to surface irrigation (8.62 q/ha). Due to improved water 
use efficiency leads to higher seed yield and drip irrigation saved 45 percent of water as compared to surface method (Yadav and Bhati, 2013). Jat et al., (2015); Amin (2004) reported that, seed and biological yield of fennel can be improved by drip irrigation level at $0.8 \mathrm{IW} / \mathrm{CPE}$ ratio as compared to surface irrigation at 1.0 IW/CPE ratio. Fennel crop can produce $3.22 \mathrm{~kg}$ seed per hectare $\mathrm{mm}$ of water and irrigating crop at 1.0 potential evaporation is ideal (Meena et al., 2016). Similarly Patel et al., (2007) stated that, irrigation at $0.9 \mathrm{IW}: \mathrm{CPE}$ ratio is optimum for higher productivity. The response of fennel to irrigation in yield improvement was found to be different in different agro-climatic and soil conditions in India. In order to improve the water use when non availability of modern irrigation techniques, the use of suitable traditional methods is important. Among them trench method of irrigation is found best for fennel crop as compared to check basin and border strip method (Bhardwaj and Agrawal, 2014). In trench irrigation, lateral movement of water in to the root zone of fennel crop leads to less evaporation and less compaction which benefited in obtaining higher seed yield. Soleymani and Shahrajabian (2012) observed that irrigating fennel crop at flowering stage is the most important for improving seed yield. In most of the studies 0.8 IW/CPE ratio yielded better in fennel.

\section{Fenugreek (Trigonella foenum-graecum)}

Fenugreek is a multipurpose crop grown for herb as well as seed. In north Indian conditions fenugreek is grown as winter crop with limited water and use of less or no fertilizers (Sharma et al., 2016). Being a legume crop among seed spices it needs less nitrogen by fixing symbiotically in root nodules but it performs positively to applied water as irrigation. Fenugreek is highly sensitive to water stress during the flowering and pod filling stages but excess irrigation may lead to heavy vegetative growth and shortening of reproductive period and ultimately decrease the yield (Sharma et al., 2016). Hence ideal irrigation level and time of irrigation is very much critical in fenugreek cultivation. Lal et al., (2013) reported that various methods of irrigation influenced the seed yield of fenugreek, among them drip irrigation method and sprinkler irrigation method recorded at par results. It because in these methods water was applied at frequent interval at right time and quantity as compared to surface irrigation. Drip system recorded 29.5 percent higher seed yield as compared to surface irrigation. Dhaker et al., (2016) reported that higher seed and haulm yield under IW: CPE ratio 1.0 is ideal for fenugreek and they find that it is favourable soil moisture during major part of crop period including critical stages (flowering and pod formation) of fenugreek crop. Sharma et al., (2016) observed that surface irrigation of fenugreek crop at two rates i.e., 0.6 IW:CPE at vegetative stage +1.0 IW:CPE at reproductive stage recorded 16.5 percent higher seed yield as compared to surface irrigation at $0.6 \mathrm{IW}$ : $\mathrm{CPE}+0.8 \mathrm{IW}$ : CPE ratio. In another study conducted by Lakpale et al., (2008) and Bhunia et al., (2015) reported that three irrigations are mandatory for fenugreek at 35, 60, 80 days after sowing and they also reported that increased number of irrigations at $0.6 \mathrm{CPE}$ or $0.8 \mathrm{CPE}$ is also beneficial for achieving higher seed yield.

\section{Nigella (Nigella sativa)}

Nigella is one of the important seed spice as well as medicinal plant cultivated for its seeds. Nigella crop takes 170-180 days to mature. Nigella crop is able to tolerate moisture stress and it can tolerate water stress except at seed formation stage (Bannayan et $a l .$, 2008). They also reported that, seed yield of nigella was reduced when irrigation was 
stopped at blooming stage which reduces the number of seeds per plant but no differences in oil content were observed by deficit irrigation. If irrigation frequency increased to six days interval by drip irrigation method at time of pre flowering and post flowering stage leads to reduction in plant growth and seed yield (El-Mekawy, 2012). It means that, ideal soil moisture is most necessary at the time of flowering seed setting stage in nigella. Using drip irrigation method in nigella, water use efficiency can be improved when irrigation is given at 50 percent of evapo-transpiration (ET) rate. Water use efficiency of nigella at 50 percent ET is $1.39 \mathrm{~kg}$ seed $\mathrm{ha}^{-1} \mathrm{~mm}$ of water (Ghamarnia et al., 2010). It is also reported that, excess irrigation causes root rot problem and low irrigation caused attack of termites in sandy soils. This is needed to be taken care to reduce the cause of these two problems in nigella cultivation.

If irrigation water is terminated at flower bud formation stage seed yield will be reduced and it is observed that, moisture stress at this stage (bud formation) increases the essential oil, carvone and thymoquinone content of seeds (Hadi et al., 2016). Hence it is utmost need to irrigate the nigella crop at flowering and seed formation stage for higher productivity.

\section{Caraway (Carum carvi L.)}

Caraway is minor seed spices grown in Himalayan tracts of India and other Mediterranean region. It is spice and also a medicinal plant used as antioxidant, antibacterial and other. The main essential oil constituents were carvone and limonene which showed an increasing of their contents under water deficit levels.

Thus, water deficit induced a significant reduction in growth parameters and fatty acid content, and an increase in the essential oil compounds at medium water stress (Laribi et al., 2009). Total fatty acids content of caraway seeds decreases significantly by about 35.17 and 56.59 percent under medium water deficit and severe water deficit, respectively, in comparison to the seeds of no moisture deficit.

\section{Celery (Apium graveolens)}

Celery is seed spice cum condiment crop used for seed and as well as leaf petiole in flavouring of food items. In India it is cultivated for seed purpose. But celery is one of the high biomass yielding crop mainly leaf and main stem which bigger in size. It is extremely sensitive to water stress leads to pithiness of petioles, which is common problem in drip-irrigated fields or low irrigated crop or short-term water stress.

It is reported that to obtain higher growth rate and quality of celery requires high soil moisture content that is not more than 20-30 percent of available water in the primary root zone to be depleted between irrigations (Hartz, 2000). Since celery is one of the higher biomass yielding crop requires more water to produce biomass.

\section{Opportunities to improve the water use efficiency in seed spices}

There are several opportunities for improving the water productivity of seed spices in India.

They are providing full irrigation to meet the full crop evapo-transpiration demand or providing supplemental irrigation in critical periods of crop growth for the rain-fed crops for increasing the crop yield

Replacing old and less effective means of irrigation with more efficient and durable methods such as drip irrigation and sprinkler irrigation system where ever necessary to increase the water use efficiency. 
As a part of good agriculture practice use of drip irrigation technique will offer safe delivering of water, pesticides, nutrients in required quantity and requires time.

Adopting transplanting techniques in seed spices such as fennel, dill, Ajwain, celery and Anise crop leads to water saving by nursery period and advancement of crop by maturity. Use of mulch materials like plastic mulching sheet, crop waste as anti-evaporates to save the irrigated water from the soil surface so that irrigation frequency can be reduced thereby saving water, energy and cost of production (Meena et al., 2014., Yadav and Bhati, 2013).

Breeding of water efficient varieties such as short duration varieties which require little irrigation as compared to long duration ones, varieties which are tolerant to moisture stress, high yielding varieties without increasing the crop consumptive use are need to be prioritize in seed spices.

Improving the water holding capacity by adding more organic matter to soil so that applied water by any means may be preserved in the soil.

Combining irrigation water, fertilizer and pesticide application to increase the efficiency of irrigation system and also input use efficiency in long duration and high nutrient demanding seed spices such as fennel, Ajwain, Nigella and celery.

Exploring the possibility of cultivation of tolerant seed spices such as cumin, dill, fennel and celery in saline and alkaline soils. Since these crops are fairly tolerant to salinity and alkalinity (Annonymus. 2015). In these conditions use of drip irrigation can yield better without increase in the salinity/alkalinity level of the soil.
Based on all the research work carried on irrigation management in seed spices to improve productivity, it is found that still more work is required to understand the crop water requirement particularly critical stages of water requirement, use of sensors in irrigation quantification. It is proved that increased irrigation level will increases the biomass content but reduces the water use efficiency in producing economic yield. This is the area where research is required to improve use efficiency of inputs such as moisture, nutrients, energy etc by various moisture retention techniques to increase the economic yield rather biological yield or it can also say that higher harvest index. Hence each and every drop of applied water is to be utilized by the crop so that higher water use efficiency can be achieved. In seed spices quality is most important along with optimum productivity hence focus on improving quality with seed yield is most necessary. In most of the studies either by drip irrigation or surface irrigation methods irrigating seed spices at 0.5-1.0 IW: CPE ratio is found optimum. But, instead of irrigating crops by visual assessment without quantifying the water leads to huge loss. It is also found that flowering and seed setting stage is most critical in coriander, fennel and nigella for its quality improvement. Hence irrigating the crop according to soil moisture status, crop need and climatic condition by following suitable moisture conservation techniques is most important in seed spices.

\section{References}

Ahmadian, A., Tavassoli, A., Amiri, E., 2011. The interaction effect of water stress and manure on yield components, essential oil and chemical compositions of cumin (Cuminum cyminum). African. J. Agric. Res. 6(10): 2309-2315.

Amin, A.V., 2004. Influence of irrigation and fertility levels on yield and uptake of 
fennel (Foeniculum vulgare mill). Agric. Sci. Digest. 24 (3): 200 - 202

Annaonymus. 2015. Vision 2050 seed spices. Indian Council of Agricultural Research, New Delhi. Pp.31.

Arvind, N.K, Subbaiah, R., Girish, V.P and Jaydip, J.M., 2016. Influence of Drip Irrigation Regimes and Lateral Spacing on Cumin Productivity. Current World Environment. 11(1): 333-337.

Bannayana, M., Nadjafi, F., Azizi, M., Tabrizi, L. and Rastgoo, M., 2008. Yield and seed quality of Plantago ovata and Nigella sativa under different irrigation treatments, Industrial Crops and Products. 27: 11-16.

Bhardwaj, R.L. and Agrawal, S.K., 2014. Effect of irrigation and crop geometry on growth, yield, quality and profitability of transplanted fennel (Foeniculum vulgare Mill.). J. of Spices and Aromatic Crops. Vol. 23 (1): 5158.

Bhunia, S.R., Chauhan, R.P.S. and Yadav, B.S., 2005. Effect of nitrogen and irrigation on water use, moistureextraction pattern, nutrient uptake and yield of fennel (Foeniculum vulgare). Indian Journal of Agronomy. 50 (1): 7376.

Bhunia, S.R., Verma, I.M., Sahu, M.P., Sharma, N.C. and Balai, K. 2015. Effect of drip irrigation and bioregulators on yield, economics and water use of fenugreek (Trigonella foenumgraecum). J. of Spices and Aromatic Crops. 24 (2): 102-105

Bondok, M.Y. and Amal, F.E, 2014. Management of sprinkler irrigation system for cumin in old Valley. Egypt. J. Agric. Res. 92 (3):1047-1061.

El-Mekawy, M.A.M., 2012. Growth and Yield of Niglla sativa L. Plant Influenced by Sowing Date and Irrigation Treatments. AmericanEurasian J. Agric. and Environ. Sci. 12
(4): 499-505.

Godara, S.R., Verma, I.M., Gaur, J.K., Suresh Bairwa and Yadav, P.K., 2013. Effect of different levels of drip irrigation along with various fertigation levels on growth, yield and water use efficiency in fennel (Foeniculum vulgare Mill.). The Asian Journal of Horticulture. 8(2): 758-762.

Hadi, M.R.H.S., Darzi, M.T. and Riazi, G., 2016. Black cumin (Nigella sativa L.) yield affected by irrigation and plant growth promoting bacteria, J. of Medicinal Plants and By-products. 2: $125-133$.

Halepyati, A.S., Sujatha, K., Prabhakar, M.M., 1996. Growth, yield, water relations and its use in tuberose (Polianthes tuberosa) as influenced by irrigation regime and nitrogen level. Indian J. Agric. Sci. 65 (12), 866-869.

Hartz T., 2000. Drip irrigation and fertigation management of celery. Celery Grower Guidelines 2000. Vegetable Research and Information Center, university of California, pp: 1-9

Hassan, F.A.S. and. Ali, E.F., 2016. Water Requirements of Drip Irrigated Cumin and Their Effects on Growth, Yield and Some Physiological As Well As Biochemical Parameters. Research Journal of Pharmaceutical, Biological and Chemical Sciences. 7(3): 178-191.

Hassan, F.A.S., Ali, E.F. and Mahfouz, S.A., 2012. Comparison between different fertilization sources, irrigation frequency and their combinations on the growth and yield of coriander plant. Australian J. of Basic and Applied Sciences. 6(3): 600-615.

Hassanzadehdelouei M., Vazin, F. and Nadaf, J., 2013. Effect of salt stress in different stages of growth on qualitative and quantitative characteristics of cumin (Cuminum cyminum L.). Cercetări Agronomice în Moldova, 1:89-97. 
Hebbar, S., Ramachandrappa, B., Nanjappa, H. V., and Prabhakar, M. 2004. Studies on NPK drip fertigation in field grown tomato (Lycopersicon esculentum Mill.). Europian J. Agron. 21(1):117127.

Jat, M.L., Shivran, A.C., Puniya, M.M., Boori, P.K., Ola, B.L. and Verma, H.P., 2015. Effect of drip irrigation scheduling on growth and seed production of fennel (Foeniculum vulgare Mill.) under semi-arid agroclimatic condition. International J. Seed Spices. 5(2): 67-73.

Jeelani, J., Katoch, K.K., Sanjeev, K.S. and Gupta, R.K., 2017. Effect of Varying Drip Irrigation Levels and Different Methods of NPK Fertilizer application on Soil Water Dynamics, Water use Efficiency and Yield of Broccoli (Brassica oleracea L. var. italica) in Wet Temperate Zone of Himachal Pradesh. Int. J. Pure App. Biosci. 5(1): 210-220.

Lakpale, R., Shrivastava, G.K. and Tripathi, R.S., 2007. Effect of irrigation schedule on growth, yield and economics of spice crops. Indian Journal of Agricultural Sciences. 77 (3):170-173.

Lal, G., Saini, I.P., Mehta, R.S., Maheria S.P. and Yash Sharma. 2013. Effect of irrigation and different seed treatment methods on growth and yield of fenugreek (Trigonella foenum graecum L.) International J. Seed Spices. 3(2):29-33.

Laribi, B., Bettaieb, I., Kouki, K., Sahli, A., Mougou, A., Marzouk, B., 2009. Water deficit effects on caraway (Carum carvi L.) growth, essential oil and fatty acid composition. Industrial Crops and Products. 31: 34-42.

Meena M., Sagarka B. K., Tania Das and Poonia T. C., 2016. Effect of drip irrigation and nitrogen levels on growth parameters and yield of drilled rabi fennel (Foeniculum vulgare Mill) in Saurashtra region of Gujarat. Res. Environ. Life Sci. 9(1): 97-99.

Meena, M., Yadav, L.R., Yadav S.S., Sharma, O.P., Choudhary, G.L. and Choudhary, P. 2014. Response of fennel (Foeniculum vulgare) to irrigation and mulching. Journal of Spices and Aromatic Crops. 23 (1): 106-109

Mehta K.G., Patel, P.G. and Patel, I.D. 1990. A new avenue of fennel cultivation in Gujarat. Indian Cocoa, Arecanut and Spices Journal. 13(4): 139-141.

Mehta, R.S., Malhotra, S.K. and Meena, S.S. 2014. Growth and yield of cumin as influenced by irrigation and nutrient levels with varying crop geometry. Indian J. Hort. 71(3): 433-436.

Moniruzzaman, M., Rahman, M.M., Hossain, M.M., Sirajul Karim, A.J.M. and Khaliq, Q.A., 2013. Effect of irrigation on seed yield and yield attributes of coriander (Coriandrum sativum L.). Bull. Inst. Trop. Agr, 36: 35-43.

Osman, A.M., El-Fiky, Y.S., 2005. Effect of applied irigaiton water amounts and plant densities on coriander (Coriandrum sativum, L.) production in sandy soils. Annual Conf Misr Soc. Agric. Eng. 22 (4): 758-770.

Parihar, S.S., Khera, K.L., Sandhu, K.S. and Sandhu, B.S., 1976. Comparison of irrigation schedule based on pan evaporation and growth stages in wheat. Agron. J. 68: 650-653.

Patel, B.S. Joshi, M.M., Patel, J.C. and Patel, N.B. 2007. Influence of irrigation based on IW: CPE ratio and nitrogen levels on yield and water use efficiency of fennel (Foeniculum vulgare Mill.). In: Malhotra S.K and Vashistha B.B (Eds). Production, Development, Quality and Export of Seed Spices, NRCSS, Ajmer, pp. 262-266.

Rao, S.S., Singh, Y.V., Regar, P.L. and Khem Chand, 2010. Effect of micro-irrigation 
on productivity and water use of cumin (Cuminum cyminum) at varying fertility levels. Indian Journal of Agricultural Sciences. 80 (6): 507-511.

Rathore, S. S., Saxena, S. N. and Balraj Singh, 2013. Potential health benefits of major seed spices. International J. Seed Spices. 3(2):1-12.

Rebey, I.B, Jabri-Karoui, I., HamrouniSellami, I., Bourgou, S., Limam, F., Marzouk, B. 2012. Effect of drought on the biochemical composition and antioxidant activities of cumin (Cuminum cyminum L.) seeds. Industrial Crops and Products. 36:238245.

Samadzadeh A., Fallahi H. R., Zamani G., Nakhaie S. and Aghhavani-Shajari M., Amirizadeh A. 2016. Impact of Super Absorbent Polymer and Irrigation Management on Seed and Essential Oil Yields of Cumin. Journal of Medicinal Plants and By-products. 2: 145-152.

Sharangi A. B. and Roychowdhury, A. 2014. Phenology and yield of coriander as influenced by sowing dates and irrigation. The Bioscan. 9(4): 15131520.

Sharma, S., Patel, R. H. and Sharma O. P. 2016. Effect of irrigation scheduling and organic manures on moisture extraction pattern, consumptive use, water use efficiency and yield of fenugreek. International J. Seed Spices. 6(2): $13-18$

Singh R., Lal G., Maheria S. P., Choudhary S., Mehta R. S. and Singh B., 2015.
Effect of irrigation techniques and planting methods on yield and water productivity of cumin (Cuminum cyminum L.). International J. Seed Spices. 5(1):92-94.

Singh,V. P., Yadav, A. C., Thakral, K. K., 2002. Effect of irrigation levels and weed control treatment on yield and quality of coriander seed. Seed Res. 30 (2): 1328-330.

Soleymani A. and Shahrajabian M. H., 2012. Response of different cultivars of fennel (Foeniculum vulgare) to irrigation and planting dates in Isfahan, Iran. Res. on Crops. 13 (2): 656-660.

Sonu, Harisha, C. B., B. Singh, Diwakar, Y., O. P. Aishwath, R. Singh, S. S. Rothore and H. Asangi, 2016. Impact of micronutrients application on growth and yield attributes of fennel (Foeniculum vulgare Mill.). International J. Seed Spices 6(1): 54-65

Tripathi M. L., Trivedi S. K. and Yadav R. P., 2009. Effect of irrigation and nutrient levels on growth and yield of coriander (Coriandrum sativum) Indian Journal of Agronomy. 54(4):454-458.

Vaidyanathan, A., Krishnakumar A., Rajagopal A. and Varatharajan D. (1994) "Impact of Irrigation on Productivity of Land", J. Indian School of Political Econ., 6(4): 601-645.

Yadav P. K. and Bhati B. S., 2013. Response of different drip irrigation volumes and mulches on yield of fennel (Foeniculum vulgare) in western part of Rajasthan. Prog. Agric. 13(1): 167-171.

\section{How to cite this article:}

Harisha, C.B., Honnappa Asangi, Ravindra Singh, N.K. Meena and Gopal Lal. 2017. Irrigation Management for Higher Productivity in Seed Spices-A Review. Int.J.Curr.Microbiol.App.Sci. 6(6): 2334-2345. doi: https://doi.org/10.20546/ijcmas.2017.606.276 